\title{
Health Education Program for Mothers Their Children Diagnosed with Favism
}

\author{
Rania Mohamed Gad El-Bastwese ${ }^{1}$, MayadaTaha Mahmoud Sabea ${ }^{2}$ \& Mohamed Ibrahim Elsamanoudy ${ }^{3}$. \\ ${ }^{1 .}$ Lecturer of Community Health Nursing Department, Faculty of Nursing, Mansoura University, Egypt. \\ ${ }^{2 .}$ Lecturer of Community Health Nursing Department, Faculty of Nursing, Helwan University, Egypt. \\ ${ }^{3 .}$ Lecturer of Department of Pediatrics, Damietta Faculty of Medicine, Al-Azhar University, Egypt.
}

\begin{abstract}
Background: Favism means a hemolytic response to the ingesting of fava beans, also identified as broad beans. Aim: Assess effect of health education program for mothers their children diagnosed with favism. Research design: A quasi-experimental design. Setting: Pediatric Outpatient Clinic in Al-Azhar University Hospital (New Damietta City), Damietta Governorate, Egypt. Sample: A convenient sample (72) of mothers their children diagnosed with favism. Tool: An interviewing questionnaire used divided to five parts: Part (1):Demographic characteristics for mothers' and their children. Part (2): Children medical history. Part (3): Mothers' knowledge regarding favism; Part (4): Mothers' attitude regarding favism; Part (5): Mothers' reported practice regarding favism. Results: present study cleared, highly statistically significant enhancement of mothers' knowledge, attitude and reported practice post health education program than pre $(5.874 \pm 2.341,4.16 \pm 2.26$ and $2.324 \pm 2.410),(25.742 \pm 2.845,23.63 \pm 2.53$ and $6.945 \pm 2.748$ )respectively .Conclusion: The health education program was effective in enhancement mothers' knowledge, attitude and practices regarding favism .Recommendations: Further researches and health education program are needed in other settings to outreach mothers for the promotion of favism knowledge, attitude and consequently practice to prevent favism complications for their children.
\end{abstract}

\section{Keywords: Health Education Program, Favism \& Mothers Their Children Diagnosed With Favism.}

\section{Introduction}

Glucose-6-phosphate dehydrogenase (G6PD) deficiency, Beans anemia or favism is an hereditary disorder caused by a genetic defect in the red blood cell (RBC) enzyme G6PD, which generates NADPH and protects $\mathrm{RBCs}$ from oxidative injury. The severity of hemolytic anemia differs among individuals with G6PD deficiency, making diagnosis more challenging in some cases. Identification of G6PD deficiency and patient education regarding safe and unsafe medications and foods is critical to preventing future episodes of hemolysis (Prchal \& Gregg, 2018) \& (Glader \& Means, 2019).

G6PD deficiency is an $\mathrm{X}$-linked disorder resulting from an alteration or mutation of the G6PD gene located at the distal end of the long arm of the $\mathrm{X}$ chromosome. Because the condition is X-linked, the disorder is more common in males; however, heterozygous females are actually the more common genotype. The expression of the genetic mutation is more common in males, as heterozygous females will likely not develop full-blown deficiency due to favorable X-chromosome inactivation. Homozygous female genotypes are extremely rare (Abolghasemi et al., 2017) \& (Harcke et al., 2019).

Favism is a life-threatening hemolytic anemia which is caused by numerous factors, as some drugs, infections, eating of cooked, fresh, frozen, , and raw fava beans (Rai \& Kumar, 2016). The World Health Organization categorizes G6PD genetic alternatives into five classes according to enzyme activity, that ranged from increase enzyme activity to severe enzyme deficiency (Den Broek et al., 2016).

The child who has the disease does not have any symptoms, unless exposed to any of the oxidizing substances that cause the breakdown of red blood cells, and these symptoms depend on the type of these oxidizing substances, and the amount taken from them, sometimes if the child intake a small amount of it don't appear any symptoms, and if Eating large amounts can lead to blood clotting or rapid destruction of red blood cells (Osman et al., 2017).

Hemolytic anemia related to favism, that is more common and severe in children, present 1 to 2 days after fava beans eating with mild fever, irritability, pallor and fatigue. Diminished oxygenation due to erythrocytelys is result in shortness of breath and tachycardia, abdominal pain, nausea, dark urine, and splenomegaly (NORD, 2019).

The diagnosis depending on take the family history especially it is a genetic disease; physical exam signs are aid in diagnosis such as Splenomegaly, Pale conjunctiva and Hyperkinetic apical pulse; some tests such as Complete blood count especially red blood cell count, Hemoglobin; Liver enzymes especially Bilirubin level, measure Hemoglobin - urine, Haptoglobin level, Lactate dehydrogenase (LDH) test, Methemoglobin reduction test and Reticulocyte count (Espino et al., 2018). 
Some foods such as legumes of all kinds and soybeans, some analgesic or hypothermia drugs such as aspirin, some anti-malarial drugs containing the term "Quine" , some chemicals such as «menthol» and some antibiotics containing the term "sulf," that lead to G6PD deficiency. Clinical symptoms of hemolytic anemia in favism occur 24-48 hours after eating FB and can last up to 5 days (Osman et al., 2016).

The care of a child complains from favism depending on awareness by the triggering factors. The bean anemia is easily controlled if the prohibited substances are avoided so that the mother should be checked anything provided to her child and make sure that free from anything of prohibited substances. The doctor should be consulted if the child is exposed to any disease to take the appropriate treatment, allowed to speak with child about his / her condition (Akoijam et al., 2016).

Nurse play important role toward community through provide health education program for mothers regarding favism and guide them about how to deal with their children because G6PDdeficiency is a potentially life-threatening. Advising the mothers to use new medicine and avoiding exposure to activating factors of hemolytic anemia (El-Sayed et al., 2012).

\section{Significance of the study}

(G6PD) lack is one of the most common genetic enzyme deficiencies foremost to hemolytic anemia affecting more than 500 million worldwide, although it has a distribution with very large variations in its prevalence ranging from zero in the original Amerindian populations to $20 \%$ in regions of Africa and Asia. Some 500 million persons with any of these mutations are mostly asymptomatic throughout their lifetime; however, any of them may develop acute and sometimes very severe hemolytic anemia (Luzzatto et al., 2020).

The occurrence of G6PD deficiency in Egypt has been re-ported to be 4: $9.9 \%$, which is higher than some other Mediterranean countries, Favism occurs most often in children aged $1-5$ years who have the Mediterranean type of G6PD deficiency. It is uncommon in adults and those with other types of G6PD deficiency (Arnaout et al., 2011) \& (Rai \&Kumar, 2016)

\section{Subjects \& Methods}

Aim of the study

Assess the effect of health education program for mothers their children diagnosed with favism.

\section{Research hypothesis}

Health education program application about favism will improve mothers' level of knowledge, attitude and reported practice.
Study Design: A quasi-experimental design was utilized to fulfill the aim of this study

\section{Setting}

The study was conducted at the pediatric outpatient clinic in Al-Azhar University Hospital (New Damietta City), Damietta Governorate, Egypt.

Subject

A convenient sample (No.= 72) of mothers they attended the outpatient clinic for receiving follow up and treatment for their children diagnosed with favism, the children were both sex and different age group was included in the study. The mothers were eligible for the study if she had a child suffering from favism.

\section{Tools and techniques of data collection}

It was developed by the researchers after reviewing related literature. An interviewing questionnaire used in the present study divided to five parts as follows:

Part (1): Socio-demographic questionnaire to gather information from:

- Mothers, such as: age, setting, occupation, marital status, educational level, income and number of family members

- Children, such as: gender and children age category.

Part (2): Children medical history which included: family history, duration of disease, history and causes of hemolytic attack, history of blood transfusion.

Part (3): Mothers' knowledge regarding favism. It was consist of (23) questions such as: meaning; causes (genetic factor; ethnic group, high risk group; exposure to viral \& bacterial infection, eating beans \&legumes, analgesic contain aspirin, antibiotic contain sulfonamides, antihistaminic drugs, antiparasitic\& anti-malarial drugs); manifestations (yellowish of eyes and skin, dizziness, change in urine color, rabid heart beats, abdominal pain, shortness breathing, fever, foot pain, tiredness and fatigue), diagnostic measures; treatment; complications and preventive measures types.(these questions used pre and post health education program).

$\Rightarrow$ The likert scale

- $0=$ no answer, I don't know or incorrect answer

- $1=$ correct incomplete

- $2=$ correct and complete

Knowledge scoring system

- Poor level $(<50 \%)(0:<23)$

- Fair level $(\geq 50 \%:<75 \%)(\geq 23:<34)$

- Good level ( $\geq 75 \%$ : 100\%)( $\geq 34: 46)$

Part (4): Mothers' attitude structured interview sheet: to determine the mothers' attitude regarding favism. It was consisted of ten statements that covering the following items (interesting to determine the new in favism disease; interesting during the attack directly visit the doctor or go to the nearest health center; feel 
the favism is a serious disease; interesting to far from foods causes attack; interesting to determine the new of favism treatment; feel the favism cause death; feel that the life difficult with favism; interesting to determine the how prevent complications; interesting to visit physician regularly; and interesting to support the child to cope with favism. (These questions used pre and post health education program). Three-point likert scales with three continuums "agree, uncertain, disagree. (3, 2 and 1 respectively) was used. If the statement was negative, the scoring system was reversed in SPSS as 3 marks were given to disagree, 2 mark was given to uncertain, and 1 was given to agree.

\section{Attitude scoring system}

- Negative $(<50 \%)(0:<15)$

- Positive ( $\geq 50 \%: 100 \%)(\geq 15: 30)$

Part (5): Mothers' reported practice regarding favism. It was consist of (8) questions such as: avoid food contain fava beans \&legumes; provide healthy diet prescribed by doctor; seeking medical advice as possible; compliance with treatment according to doctor orders; going to hospital during hemolytic crisis; avoid exposure to undesired infection; avoid drug administration without doctor order; and compliance with periodic checkup\& follow-up of disease (these questions used pre and post health education program).

$\Rightarrow$ The likert scale: This part contain 8 questions, were coded as following

- $\quad$ Not done $=$ zero

- Done $=1$

Reported practice scoring system

- Inadequate practice $(<50 \%)(0:<4)$

- Adequate practice ( $\geq 50 \%: 100 \%)(\geq 4: 8)$

Validity

The validity of tools content tested by 5 experts in the field of Community Health Nursing and pediatric medicine.

\section{Reliability}

Reliability coefficients were calculated for questionnaires of:

- Assess mothers' knowledge questionnaire, Cronbach's Alpha $=0.89$.

- Assess mothers' attitude questionnaire, Cronbach's Alpha $=0.87$.

- Assess mothers' reported practice questionnaire, Cronbach's Alpha $=0.88$.

\section{Pilot Study}

A pilot study was carried out on 8 (about $10 \%$ of the study sample) of mothers their children diagnosed with favism and excluded from the total sample. It was done to notice any ambiguity in the tools, to ensure transparency of the items, as well as, to find out the time devoted to data collection. Needed modifications were carried out.

\section{Ethical consideration}

The researchers explained the study aim for mothers and then oral consent obtained. The researchers ensure that all data was confidential, used only for research purpose and the studied sample has rights to withdraw at any time of the study.

\section{Field work}

Before carry out the study the official permission was taken from Al-Azhar University Hospital (New Damietta City) manager. The study was carried out from the beginning of July2019 until December 2019 for data collection and program application. The researchers visit the study settings three days/week from 9.00 am to $12.00 \mathrm{pm}$.

\section{The field work was directed in following phases} Assessment phase

Researchers greeted the mothers their children diagnosed with favism, then explained the study aim, and they filled in pretest questionnaire. The time spent to fill the questionnaire was $15-20$ minutes.

\section{Planning \&designing phase}

Health education program content was designed in simple Arabic language and clear illustration pictures to improve mothers' knowledge, attitudes and practices regarding favism after reviewing of related literatures .The researchers interest to put sentence improve mothers' attitude regarding favism such as importance for mothers to know that the natural the disease; also program cleared the mothers' practice regarding favism such as: importance of avoid food contain fava beans \&legumes; provide healthy diet prescribed by doctor. The health education program regarding favism was provided also to mothers knowledge regarding favism, such as: meaning; causes; manifestations, diagnostic measures; treatment; complications and preventive measures.

Implementation phase

Three sessions were given to every group of mothers) average 10) in each session. Every session consumed 30 minutes to be finished. The application done in special room in outpatient clinic - Different teaching strategies were used to the small groups in application of the health education program .The researchers were using laptop screen for data show. A brochure was distributed to all studied sample.

Evaluation phase: Was conducted after one month of health education program application by using the same preprogram questionnaire.

\section{Statistical analysis}

The collected data were organized, tabulated and statistically analyzed using SPSS software (version 22, SPSS Inc. Chicago, IL, USA). For quantitative data, the range, mean and standard deviation were 
calculated. For qualitative data, which describe a categorical set of data by frequency, percentage or proportion of each category. Qualitative variables were measured by using chi-square test $(\chi 2)$.Statistical significant was considered at Pvalue $<0.05$. Pearson correlation coefficients were used to estimate the correlation between the study variable to clarify positive or negative correlation

\section{Results}

Table (1): Distribution of the studied mothers according to their socio demographic Characteristics (N=72).

\begin{tabular}{|c|c|c|}
\hline Item & No. & $\%$ \\
\hline $\begin{array}{l}\text { Mothers age category } \\
<20 \text { years } \\
20-<30 \text { years } \\
30 \geq 40 \text { years }\end{array}$ & $\begin{array}{l}15 \\
44 \\
13\end{array}$ & $\begin{array}{l}20.8 \\
61.1 \\
18.1\end{array}$ \\
\hline \multicolumn{3}{|c|}{ Mean \pm SD $(24.65 \pm 5.45)$} \\
\hline $\begin{array}{l}\text { Setting: } \\
\text { Rural } \\
\text { Urban }\end{array}$ & $\begin{array}{l}54 \\
18\end{array}$ & $\begin{array}{l}75 \\
25\end{array}$ \\
\hline $\begin{array}{l}\text { Occupation: } \\
\text { Housewife } \\
\text { Employee }\end{array}$ & $\begin{array}{l}52 \\
20 \\
\end{array}$ & $\begin{array}{r}72.2 \\
27.8 \\
\end{array}$ \\
\hline $\begin{array}{l}\text { Marital status: } \\
\text { Married } \\
\text { Divorced } \\
\text { Widow } \\
\end{array}$ & $\begin{array}{c}62 \\
5 \\
5 \\
\end{array}$ & $\begin{array}{c}86.1 \\
6.9 \\
6.9 \\
\end{array}$ \\
\hline $\begin{array}{l}\text { Educational level: } \\
\text { Illiterate } \\
\text { Primary } \\
\text { Preparatory } \\
\text { Secondary } \\
\text { University } \\
\end{array}$ & $\begin{array}{c}26 \\
7 \\
9 \\
14 \\
16 \\
\end{array}$ & $\begin{array}{c}36.1 \\
9.7 \\
12.5 \\
19.4 \\
22.2\end{array}$ \\
\hline $\begin{array}{l}\text { Income: } \\
\text { Not enough } \\
\text { Enough } \\
\text { Enough and save }\end{array}$ & $\begin{array}{c}62 \\
5 \\
5 \\
\end{array}$ & $\begin{array}{c}86.1 \\
6.9 \\
6.9 \\
\end{array}$ \\
\hline $\begin{array}{l}\text { Family members } \\
\text { Less than or equal3 } \\
>3\end{array}$ & $\begin{array}{l}21 \\
51\end{array}$ & $\begin{array}{l}29.2 \\
70.8\end{array}$ \\
\hline
\end{tabular}

Table (2): Socio -demographic characteristics of studied children with favism $(\mathrm{N}=72)$

\begin{tabular}{|c|c|c|}
\hline Item & $\mathbf{N}$ & $\%$ \\
\hline $\begin{array}{l}\text { Children age category } \\
1<5 \text { years } \\
5 \text { - }<10 \text { years } \\
\geq 10 \text { years }\end{array}$ & $\begin{array}{l}18 \\
40 \\
14\end{array}$ & $\begin{array}{c}25 \\
55.6 \\
19.4\end{array}$ \\
\hline \multicolumn{3}{|c|}{ Mean \pm SD $(5.72 \pm 3.553)$} \\
\hline $\begin{array}{l}\text { Gender: } \\
\text { Male } \\
\text { Female }\end{array}$ & $\begin{array}{l}56 \\
16\end{array}$ & $\begin{array}{l}77.8 \\
22.2\end{array}$ \\
\hline
\end{tabular}


Table (3):Distribution of studied children with favism according to medical history ( $N=72)$.

\begin{tabular}{|l|c|c|}
\hline \multicolumn{1}{|c|}{ Items } & No & \% \\
\hline Family history of disease & 17 & 236 \\
Negative & 55 & 76.4 \\
Positive & & \\
\hline Duration of disease & 9 & 12.5 \\
<1 year s & 40 & 55.6 \\
1-3years & 5 & 6.9 \\
>3-6 years & 18 & 25 \\
\hline 6 years & 46 & 63.9 \\
\hline History of hemolytic attack & & \\
\hline Causes of attack & 42 & 58.3 \\
Eating of Beans & 2 & 2.8 \\
Viral and bacterial infection & 26 & 36.1 \\
Drug intake as Asprin & 2 & 2.8 \\
Inhalation of Beans powders & & \\
\hline Attack duration & 13 & 9.7 \\
No attacks & 7 & 51.4 \\
1: 2 days & 37 & 15.3 \\
2:<4 days & 11 & 5.6 \\
$4:<6$ days & 4 & 58.3 \\
$\geq 6$ & 42 & 33.3 \\
\hline History of blood transfusions & & 23.6 \\
\hline Relatives complain same disease & 24 & 15.3 \\
Father & 17 & 4.2 \\
Mother & 11 & 23.6 \\
Uncle & 3 & 9.7 \\
Grand parents & 17 & 90.3 \\
Non & & \\
\hline Child complain from Chronic diseases & 7 & \\
Diabetes mellitus & 65 & \\
Don't complain & & \\
\hline
\end{tabular}

Table (4): Difference of total scores knowledge level pre and post health education program among the studied mothers $(\mathbf{N}=72)$.

\begin{tabular}{|c|c|c|c|c|c|c|}
\hline \multirow[t]{3}{*}{ Total scores Knowledge } & \multicolumn{4}{|c|}{$\begin{array}{l}\text { The mothers their children diagnosed } \\
\text { with favism }(n=72)\end{array}$} & \multicolumn{2}{|c|}{ Test of significance } \\
\hline & \multicolumn{2}{|c|}{ Pre } & \multicolumn{2}{|c|}{ post } & \multirow{2}{*}{$\chi^{2}$} & \multirow{2}{*}{$P$ value } \\
\hline & No. & $\%$ & No. & $\%$ & & \\
\hline - Poor level $(0:<23)$ & 61 & 84.7 & 10 & 13.9 & \multirow{3}{*}{57.87} & \multirow{3}{*}{$0.0001 *$} \\
\hline - Fair level $(\geq 23:<34)$ & 11 & 15.3 & 58 & 80.6 & & \\
\hline - Good level ( $\geq 34: 46)$ & - & - & 4 & 5.5 & & \\
\hline $\begin{array}{l}\text { Range } \\
\text { Mean + SD }\end{array}$ & \multicolumn{2}{|c|}{$(10-20) 10$} & \multicolumn{2}{|c|}{$(20-30) 10$} & \multicolumn{2}{|c|}{$0.0001 *$} \\
\hline
\end{tabular}

$(*)$ Statistically significant at $p \leq 0.05, \square:$ mean, SD: standard deviation 
Table (5): Difference of attitude pre and post health education program among the studied mothers ( $N=72)$.

\begin{tabular}{|c|c|c|c|c|c|c|}
\hline \multirow{3}{*}{ Mothers Attitude } & \multicolumn{4}{|c|}{$\begin{array}{l}\text { The mothers their children diagnosed } \\
\text { with favism }(n=72)\end{array}$} & \multicolumn{2}{|c|}{ Test of significance } \\
\hline & \multicolumn{2}{|c|}{ Pre } & \multicolumn{2}{|c|}{ post } & \multirow{2}{*}{$\chi^{2}$} & \multirow{2}{*}{$P$ value } \\
\hline & No. & $\%$ & No. & $\%$ & & \\
\hline - Negative $(<50 \%)(0:<15)$ & 59 & 81.9 & 14 & 19.4 & \multirow{2}{*}{43.179} & \multirow{2}{*}{$0.0001^{*}$} \\
\hline - Positive $(\geq 50 \%:<100 \%)(\geq 15:<30)$ & 13 & 18.1 & 58 & 80.6 & & \\
\hline $\begin{array}{l}\text { Range } \\
\text { Mean } \pm \text { SD }\end{array}$ & \multicolumn{2}{|c|}{$\frac{1}{(13-2) 11}$} & $(28-17) 11$ & $\begin{array}{l}111 \\
2.53\end{array}$ & \multicolumn{2}{|c|}{$0.0001 *$} \\
\hline
\end{tabular}

(*) Statistically significant at $p \leq 0.05, \square:$ mean, SD: standard deviation

Table (6): Difference of total scores reported practice pre and post health education program among the studied mothers $(\mathrm{N}=72)$

\begin{tabular}{|c|c|c|c|c|c|c|}
\hline \multirow{3}{*}{ Total score reported practice } & \multicolumn{4}{|c|}{$\begin{array}{l}\text { The mothers their children diagnosed } \\
\text { with favism }(n=72)\end{array}$} & \multicolumn{2}{|c|}{ Test of significance } \\
\hline & \multicolumn{2}{|c|}{ Pre } & \multicolumn{2}{|c|}{ post } & \multirow[t]{2}{*}{$\chi^{2}$} & \multirow[t]{2}{*}{ P value } \\
\hline & No. & $\%$ & No. & $\%$ & & \\
\hline $\begin{array}{l}\text { - Inadequate practice } \\
(<50 \%)(0:<4)\end{array}$ & 52 & 72.2 & 10 & 13.9 & \multirow{2}{*}{64.247} & \multirow{2}{*}{$0.0001 *$} \\
\hline $\begin{array}{l}\text { - Adequate practice } \\
\text { - }(\geq 50 \%: 100 \%)(\geq 4:<8)\end{array}$ & 20 & 27.8 & 62 & 86.11 & & \\
\hline $\begin{array}{l}\text { Range } \\
\text { Mean } \pm \mathrm{SD}\end{array}$ & \multicolumn{2}{|c|}{$\begin{array}{c}(1-4) 3 \\
2.324 \pm 2.410\end{array}$} & \multicolumn{2}{|c|}{$\begin{array}{c}(5-8) 3 \\
6.945 \pm 2.748\end{array}$} & \multicolumn{2}{|c|}{$0.0001 *$} \\
\hline
\end{tabular}

(*) Statistically significant at $p \leq 0.05, \square:$ mean, SD: standard deviation

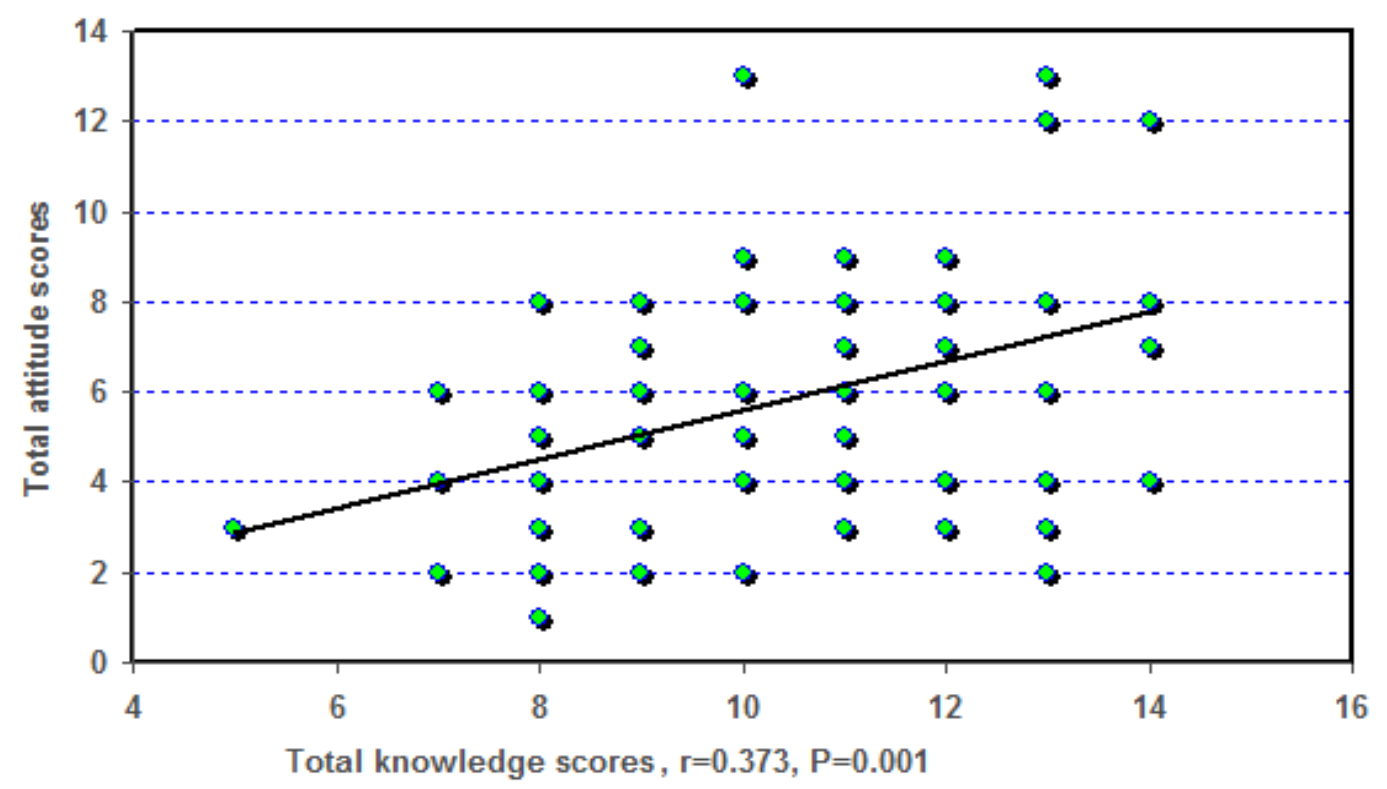

Figure (1): Correlation between total knowledge and total attitude regarding Educational Program for mothers their children diagnosed with favism post Health Education Program, (N=72). 


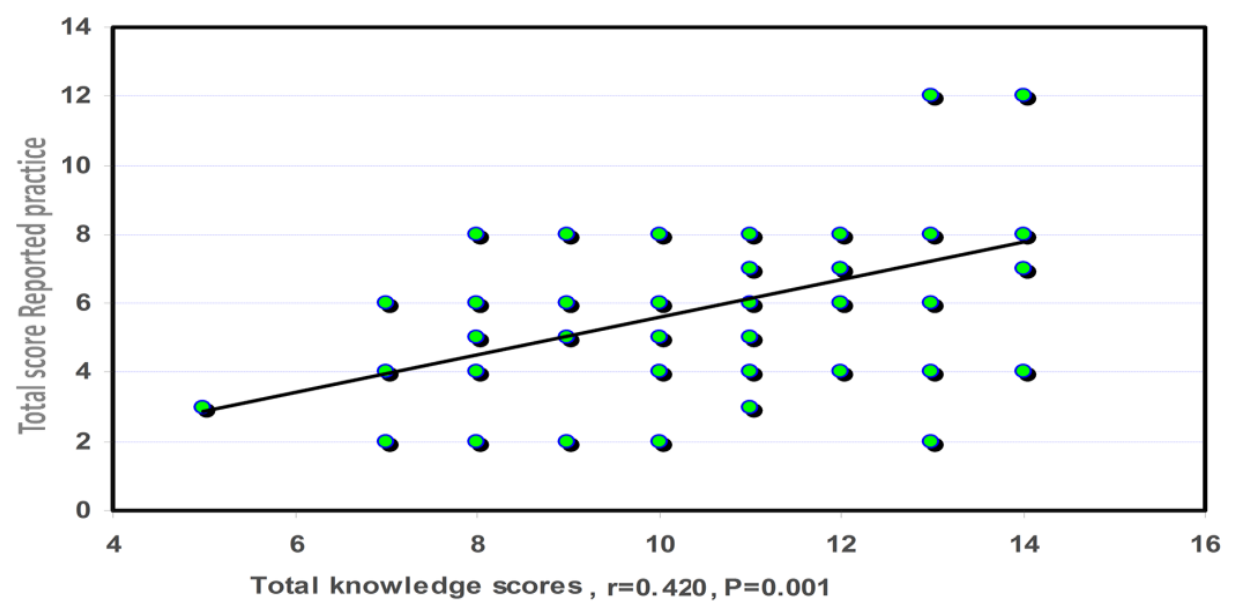

Figure (2): Correlation between total knowledge and total Reported Practice Regarding Educational Program for Mothers their Children Diagnosed with Favism post Health Education Program,(N=72).

Table (1): Cleared the mothers socio-demographic characteristics. It was $61.1 \%$ of mothers were aged 20 - <30 years, while $75 \%$ lives in rural area, $72.2 \%$ of them housewife also $86.1 \%$ of them married, $36.1 \%$ was illiterate, while $86.1 \%$ of them had not enough income and $70.8 \%$ of them their family members more than three.

Table (2): Showed the children with favism sociodemographic characteristics. It was more than half $55.6 \%$ of them were aged $5-<10$ years, and $77.8 \%$ of them male.

Table (3): Illustrated children with favism medical history, it was observed that $76.4 \%$ of them had positive family history of favism, $55.6 \%$ of them the disease duration from 1-3years, also $58.3 \%$ of them causes of attack was eating of beans, and $33.3 \%$ of them their father complain from same disease.

Table (4): Stated that highly statistically significant enhancement in total score knowledge of mothers their children diagnosed with favism post health education program than pre, $\mathrm{P}<0.001$.

Table (5): Showed that highly statistically significant enhancement in total score attitude of mothers their children diagnosed with favism post health education program than pre, $\mathrm{P}<0.001$.

Table (6): Indicated that highly statistically significant enhancement in total score reported practice of mothers their children diagnosed with favism post health education program than pre, $\mathrm{P}<$ 0.001 .

Figure (1): Presented that positive correlation between total knowledge and total attitude regarding health education program for mothers their children diagnosed with favism post health education program, $r=0.373$ combined with highly statistically differences
Figure (2): Presented that positive correlation between total knowledge and total reported practice regarding health education program for mothers their children diagnosed with favism post health education program, $r=0.420$ combined with highly statistically differences.

\section{Discussion}

Favism is a threatening life hemolytic anemia that result from the eating fava and broad beans. Glucose 6 Phosphate dehydrogenase is a metabolic enzyme is involved in pentose phosphate pathway, especially important in red blood cell metabolism it also protects red blood cells from the effects of potentially harmful molecules (Isbir et al., 2013).

The present study revealed that, near to two thirds of mothers were aged $20-<30$ years while three quarters were lives in rural area. These results agree with ((El-Sayed et al., 2012) who deliberate "Prevention of Hemolytic Crisis among G6PD Children: Effect of Educational Program Intervention" in Egypt, who cleared that $60 \%$ of mothers were aged $25-<35$ years, and $73 \%$ of studied sample lives in rural area

The current study also revealed that less than three quarters $(72.2 \%)$ of them housewife likewise majority $(86.1 \%)$ of them married, slightly more than one third $(36.1 \%)$ was Illiterate, while majority $(86.1 \%)$ of them had not enough income. These results in the same contrast with (Pradeep et al., 2016), who studied "Prevalence of glucose-6phosphate dehydrogenase deficiency in India: An updated meta-analysis" and presented that $70 \%$ of studied sample housewife and $83 \%$ of them married, also cleared that $35 \%$ of them was illiterate and $80 \%$ of them had not enough income 
The current study cleared that $(55.6 \%)$ of children were aged $5-<10$ years, and $(77.8 \%)$ of them male. These distribution for study characteristics agree with (Rai \& Kumar, 2016) who examine "Glucose 6phosphate dehydrogenase deficiency in Muslim community settled" in Jaunpur district, Indian and showed $51 \%$ of children were aged $5-<10$ years, and $76 \%$ of them male.

The present study correspondingly showed more than three quarters $(76.4 \%)$ of the studied sample had family history of favism, while more than half $(55.6 \%)$ of them the disease duration from 1-3years, also more than half $(58.3 \%)$ of them eating of beans causes attack.( Deniz et al., 2017) who studied "Tools for mass screening of G6PD deficiency: validation of the WST8/1-methox y-PMS enzymatic assay in Uganda" showed that $72 \%$ of the studied sample had family history of favism, $52 \%$ of them the disease duration from 1-3 years, $53 \%$ of them eating of beans causes attack. The current study showed that less than one third $(33.3 \%)$ of them their father complain from same disease. This is consistent with (Espino et al., 2018)Which search "Comparison of Three Screening Test Kits for G6PD Enzyme Deficiency: Implications for Its Use in the Radical Cure of Vivax Malaria in Remote and Resource-Poor Areas in the Philippines" who illustrated 29\% of studied sample their father complain from favism (G6PD).

The present study displayed that highly statistically significant enhancement in total score knowledge of mothers their children diagnosed with favism health education program than pre. This is in agreement with(Osman et al., 2017) who studied "Identification of Mediterranean mutation in Egyptian favism patients" showed that highly statistically significant enhancement in total score knowledge of caregivers of children with favism post program than pre, also the result agree with (Minucci et al., 2017) who "Glucose-6-phosphate dehydrogenase (G6PD) mutations database: review of the old and update of the new mutations" in United State of America who mentioned that statistically significant enhancement in total score knowledge post intervention than pre. The results in this study indicated that highly statistically significant enhancement in total score reported practice of mothers their children diagnosed with favism post educational program than pre. This finding consistent with (Al-(Allawi et al., 2016)who studied that "Prevalence and molecular characterization of glucose-6-phosphate dehydrogenase deficient variants among the Kurdish population of Northern Iraq" who illustrated that statistically significant enhancement in total score practice post program than pre.
The current study clarified that, highly statistically significant enhancement in total score attitude of mothers their children diagnosed with favism post educational program than pre. This finding agree with (Al-Musawi et al., 2014) who studied "Molecular characterization of glucose-6-phosphate dehydrogenase deficient variants in Baghdad city Iraq" they mentioned that statistically enhancement in the studied sample attitude after the program than before it.

The results revealed highly statistical significant positive correlation between total mean scores knowledge, total mean scores reported practice and attitude of mothers their children diagnosed with favism pre and post educational program. These findings were supported by(Balgir, R., 2018), who studied "Intervention and Prevention of Hereditary Hemolytic Disorders in Two Ethnic Communities of Sundargarh, District of Orissa, India" who mentioned that statistical significant positive correlation between total Mean knowledge scores, total Mean practice scores. From the researchers point of view it mean that the mothers' knowledge improved their attitude and practice toward favism.

Concerning to correlation between total knowledge and total attitude regarding health education program for mothers their children diagnosed with favism post health education program the current study cleared positive correlation, $\mathrm{r}=0.373$ with highly statistically differences. This finding is supported by (Hky-Lau, 2018) who studied "Acute Massive Hemolysis in Children with Glucose6 phosphate Dehydrogenase Deficiency: Health Education Program" in Hong Kong who illustrated that positive correlation between total knowledge and total attitude regarding health education program, $r=0.410$ with highly statistically differences.

\section{Conclusion}

The health education program was effective in enhancement the mothers' knowledge, attitude and practices regarding to favism.

\section{Recommendations}

Further researches are needed in other setting and implement health education program for mothers their children diagnosed with deficiency of enzyme 6 (favism) to prevent complication and generalize the results.

\section{References}

- Abolghasemi H., Mehrani H., \& Amid A., (2017): An update on the prevalence of glucose-6phosphate dehydrogenase deficiency and neonatal jaundice in Tehran neonates.Clinical Biochemistry, 37: 241244. 
- Akoijam, S., Malar, K., Akoijam, M., (2016): Living with Glucose-6-Phosphate Dehydrogenase Deficiency,Journal of Nursing Science\&Practice,ISSN:2249-4758(online) volume 6, available at: http://www.researchgate.net

- Al-Allawi, N., Eissa, A., Jubrael, J., Jamal, S., \& Hamamy, H., (2016): Prevalence and molecular characterization of glucose-6-phosphate dehydrogenase deficient variants among the Kurdish population of Northern Iraq. BMC Blood Disord; 10: 6.

- Al-Musawi B., Al-Allawi N., Abdul-Majeed B., Eissa A., Jubrael J., \& Hamamy H., (2014): Molecular characterization of glucose-6-phosphate dehydrogenase deficient variants in Baghdad city Iraq. BMC Blood Disord; 12: 4.

- Arnaout, Hanaa H., Nesrine M., El-Gharbawy, Iman A., Shaheen, Reham A., Afifi, \& Omnia Y., Abd EL-Dayem, (2011): "Incidence and Association of $563 \mathrm{C} / \mathrm{T}$ Mediterranean and the Silent 1311C/T G6PD Mutations in G6PD-deficient Egyptian Children" , Laboratory Medicine,.

- Balgir, R., (2018): Intervention and Prevention of Hereditary Hemolytic Disorders in Two Ethnic Communities of Sundargarh, District of Orissa, India: An Experience From Kap Studies. Online Jhealth Allied Scs.;9(3):4, Url: http://www.ojhas.org/issue35/2010-3-4.htm

- Den Broek L., Heylen E., \& Den Akker M., (2016): Glucose-6-phosphate dehydrogenase deficiency: not exclusively in males, clinical case report, v.4(12); Dec., PMC5134135, avaliable at: https://www.ncbi.nlm.nih.gov/pmc/articles/PMC51 34135/pdf/CCR3-4-1135.pdf

- Deniz, M., Eziefula, A., Othieno, L., Mbabazi, E., Nabukeera, D., \& Ssemmondo, E., (2017): Tools for mass screening of G6PD deficiency: validation of the WST8/1-methoxy-PMS enzymatic assay in Uganda. Malar J.; 12: 210. doi: 10.1186/1475-2875-12-210 PMID: 23782846

- El-Sayed, L., Tantawi, H., Adly, A., \& Farouk M., (2012):Prevention of Hemolytic Crisis among G6PD Children: Effect of Educational Program Intervention, available at:http://www.jofamericanscience.org

- Espino, F., Bibit, J., Sornillo, J., Tan, A., Seidlein, L., \& Ley, B., (2018): Comparison of Three Screening Test Kits for G6PD Enzyme Deficiency: Implications for Its Use in the Radical Cure of Vivax Malaria in Remote and ResourcePoor Areas in the Philippines. PLo S One; 11: e0148172. doi: 10.1371/journal. pone.0148172 PMID: 26849445

- Glader, B., \& Means J., (2019): Diagnosis and management of glucose-6-phosphate dehydrogenase (G6PD) deficiency. Up To Date.
Waltham, MA UptoDate Inc. http://www. uptodate. com (Zugriff am 11.9. 2018).

- Harcke, S., Rizzolo, D., \&Harcke, H., (2019): G6PD deficiency: An update. Journal of the American Academy of PAs, 32(11), 21-26.

- Hky-Lau, F., (2018): Acute Massive Hemolysis in Children With Glucose-6- hosphate Dehydrogenase Deficiency: Health Education Program, Hong Kong med j;12:149-51

- Isbir, T., Gormus, U., \& Dalan, A., (2013): Brenre's Encyclopedia of Genetics (Favism) 2013, $2^{\text {nd }}$ ed ., 22-23 online book at science direct .com

- Luzzatto, L., Ally, M., \& Notaro, R., (2020): Glucose-6-phosphate dehydrogenase deficiency. Blood, The Journal of the American Society of Hematology, 136(11), 1225-1240. )

- Minucci, A., Moradkhani, K., Hwang, M., Zuppi, C., Giardina, B., \& Capoluongo, E., (2017): Glucose-6-phosphate dehydrogenase (G6PD) mutations database: review of the "old" and update of the new mutations in United State of America. Blood Cells Mol Dis.; 48: 154:165. doi: 10.1016/j.bcmd.01.001 PMID: 22293322

- NORD (National Organization for Rare Disorders (2019): Tools for mass screening of G6PD deficiency: validation of the WST8/1methox y-PMS enzymatic assay in Uganda, available at: https://rarediseases.org/rarediseases/glucose-6-phosphate-dehydrogenasedeficiency, Accessed July 24, 2019.

- Osman, H., Zahran, F., \& El-Sokkary, A., (2016): Oxidative stress and antioxidant defense in Egyptian favism patients. Eur Rev Med Pharmacol Sci; 17(9):1211-7.

- Osman, H., Zahran, F., EL-sokkary, A., EL-Said A., \& Sabry, A., (2017): Identification of Mediterranean mutation in Egyptian favism patients, European Review for Medical and Pharmacological Sciences, 18: 2821-2827, avaliable

at: https://pubmed.ncbi.nlm.nih.gov/25339475/

- Pradeep, K., Upendra, Y., \& Vandana, R., (2016): Prevalence of glucose-6-phosphate dehydrogenase deficiency in India: An updated meta-analysis, available at: https://www.sciencedirect.com/science/article/pii/S 1110863016000185?via\%3Dihub

- Prchal, J., Gregg, X., (2018): Red cell enzymopathies. In: Hoffman R, Benz E, Haematology: Basic Principles and Practice, $4^{\text {th }}$ ed. Churchill living stone Philadelphia pp. 653-659.

- Rai, V., Kumar, P., (2016): Glucose 6-phosphate dehydrogenase deficiency in Muslim community settled in jaunpur district. Indian J Hum Genet; 20(1):96-7. 